wynikającymi z godności Macierzyństwa Najśw. Panny. Wykazać by zaś powinien, że wynikają one $z$ tekstu.

Chociaż tedy trudno zgodzić się na ostateczną konkluzję autora, że Wniebowziẹcie Matki Najśw. jest „formaliter implicite“ objawione przez Boga w Piśmie św., to jednak niemniej pracę jego uważać można, ze względu na zawarte $w$ niej inne argumenty, za ważny przyczynek w przygotowaniach do ogloszenia tej prawdy jako dogmat.

Bielsko

Ks. Konrad Marklowski.

\title{
Wiadomości liturgiczne
}

\section{Z WŁOCH}

Genueńskie Apostolstwo Liturgiczne urzạdzilo „I narodowy Tydzień Liturgiczny." w Parmie pod kierowniciwem ks. biskupa Bernareggi. Uczestników liylo okolo 150 osób. Omawiano przede wszystkim tematy związane z encyklika „Mediator Dei“. Wykłady: (). Canizzaro („Religia a liturgia“), ks. biskupa Rossi („Rola hierarchii w liturgii“), O. Opata Capelle („O całości kultu Ciada Mistycznego") i inne wywolaly iywa dyskusję. Uchwalono utworzenie stalego ośrodka działalności (C. A. L..), który by popierał naukę, kszatałtował ducha, doskonalil kult, usuwal naduzycia, który by wreszcie jednoczyl wysilki.

Umarl w Rzymie zaslużony profesor Kolegium św. Anzelma, O. Fil ip Op pen heim. autor wielotomowego dziela p. t. "Institutiones liturgicac" $\mathrm{i}$ innych.

Sw. Kongregacja ,de disciplina sacramentorum“ wydała 1. 10. 1949 r. pouczenie dotyczące kaplic prywatnych i przechowywania w nich Najświętszego Sakramentu, prawa odprawiania Mszy św. przy przenośnym ołtarzu i bez ministranta. Pozwolenie na kaplice prywatne i ołtarze przenośne udziela się tylko dla rzeczywistej potrze by $\mathrm{i}$ to $w$ mierze bardzo ograniczonej, majac zawsze na oku dobro ogólu. Șw. Kongregacja przypomina, ze Msze św., pierwotnie odprawiane $z$ uroczystą asystą, nie mogą się odbywać bez jakiegoś jednego przynajmniej przedstawiciela Koscioła św. Tylko w wyjątkowych wypadkach np. wobec konieczności konsekrowania dla udzielenia Wiatyku, dla dokończenia św. Ofiary, jeśliby akolita odszedl od oltarza po rozpoczęciu Mszy Sw., może to mieć miejsce, jak równiez za specjalnym pozwoleniem Stolicy sw., dawanym przede wszystkim dla krajów misyjnych. Niewiasta gdy jej wypadnie zastạpić akolitẹ z dala tylko może odpowiadać kaplanowi, nigdy nie przystẹpując do oltarza. Prøy udzielaniu pozwolenia na przechowywanie Najświętszego Sakramentu trzeba micé zawsze na oku główny i pierwotny tego cel, a mianowicie udzielenie wiatyku w wypadku ginożącej śmierci. Ponieważ w kaplicach prywatnych zwykle ten cel nie przyświeca, a duże jest pole naduźyć, pozwolenia bẹdą wyjątkowe. 


\section{Z AUSTRII}

Salzburskie czasopismo „Kerusblatt“ zamieściło list kardynała MarchettiSalviagani z wyjaśnieniem, że pewne zwroty encykliki „Mediator Dei“ odnoszą się do teorii misteriologicznej $\mathrm{O}$. Casela z Maria-Laach. Kardynal-Sekretarz św. Officium pisze, że Ojciec św. z tymi poglądami się nie godzi, a nawet się od nich oddala (dass sich der hl. Vater mit dieser u. ähnlichen Ansichten nicht identifiziert, sondern sich vielmehr davon ziemlich klar distanziert). Chodzi tu o zagadnienie obecności tajemnic w kulcie liturgicznym. Ojciec św. wyraża się jasno, że są one obecne i dzialają nie w jakiś mglisty i nieokreślony sposób, ale sạ wzniosłymi przykładami dla doskonalości chrześcijańskiej i przez zaslugi i modlitwy Chrystusa źródlami łask, a skutki ich trwają w nas, jako, że poszczególne są na swój sposób przyczyną naszego zbawienia. Kardynał przypomina te $\dot{z}$, i przeciwstawienie wartości modlitwy prywatnej i publicznej jest przeciwne myśli Ojca św.

\section{Z NIEMIEC}

W nadreńskim opactwie Maria Laach istnieje "Instytut Herwegena“, gdzie dotąd zajmowano się badaniami nad liturgią i historią zakonu. Obecnie Instytut rozszerzył swe zainteresowania na dziedzini Pisma św. i Ojców Kościola, archeologii i śpiewu gregoriańskiego. Owoce pracy ogłasza się w całym szeregu stałych wydawnictw, które silnie oddzialują na cały niemiecki ruch liturgiczny zarówno wśród kleru, jak i w kolach świeckich. W Niemczech mówi się też dużo o szerszym stosowaniu języka narodowego w liturgii. Czy nie łzatrze to tego znamienia świętośoi, które język laciński nabył w ciągu wieków?

Rozwija się również korzystnje ruch wydawniczy. Ciekawy i wiele mówiący jest zwrot do źródel: wśród nowości spotykamy „De sacramentis“ św. Ambrożego, „Konstytucje apostolskie“, sakramentarze, lekcjonarze itp., które podobno przynoszą ważne przyczynki do historii liturgii.

\section{Z HOLANDII}

Zjazd w norbertańskim opactwie w Bernie umożliwil spotkanie około 50 uczonych liturgistów. Obradowano nad zagad. stosunku mas wiernych do liturgii, jak dotąd bawiem interesowała siẹ ruchem zaledwie cząstka elity. Wskazówki daje encyklika „Mediator Dei“. Podkreślono potrzeby szerszego użytkowania języka żywego, zwłaszcza w rytuale i w czytaniach podczas Mszy św., którą kapłani powinni wyjaśniać i zachęcać lud do łączenia się z Najśw. Ofiarą przez przyjmowanie Komunii św.

O. Stalleart, Redemptorysta, opracowuje wyciąg z brewiarza, który ma zachować części wlasne świąt i okresów liturgicznych z pominięciem psalmów. W ten sposób pragnie autor ułatwić osobom świeckim życie z Kościolem św. Wyciąg ten może w niektórych zgromadzeniach zastạpić małe Officium M. B. 


\section{Z BELGII}

Kongres „Misie Konferentie“, który się odbył w dniach 5-6 lipe at w Antwerpii, zająl się przede wszystkim życiem eucharystycznym paräii. O. Dekers mówil o roli liturgii w czasie misji parafialnych, a wiẹc o potrzebie zbliżenia wiernych do spraw kultu, odprawiania i wyjaśniania Mszy św., urządzania tinnych nabożeństw liturgicznych, moźliwie z bogactwem ceremonii. Równiéz w kazaniach należy omawiać te tematy i wykorzystywać myśl przewodnią okresu liturgicznego.

W Tournai urządzono wystawę sztuki kościelnej. Ciekawe i wartościowe rzeczy znalazly się w dziale szat litırgicznych i zlotnictwa, natomiast gorzej się przedstawia dorobek malarstwa i rzeźby. O czymś podobnym ezytamy również w sprawozdaniach $z$ innych krajów.

W dniach 5-5 października Zjazd liturgiczny w opactwie Mont César omawial potrzebę i moźliwość dostosowania brewiarza do warunków i potrzeb chwili. $Z$ zewsząd podnoszą siẹ skargi, że brewiarz w obecnym stanie jest niezrozumiały i zupelnie niezdolny do spelnienia swych zadań w duszy kaplańskiej. Przyczyn jest wiele: nieznajomość języka, dlugość niektórych godzin kanonicznych, niedomogi kalendarza, wreszcie dobór czytań bez głẹbszego duchowego znaczenia i sam psałterz nastrẹczają niezwalczone trudności. Zwrócono się z prośbą do Stolicy św. Dziś juź wiemy, ze Ojciec św. powierzyl opracowanie projektu reformy O. Bernardowi Capelle, Opatowi z Louvain. Przebudowa ta jednak - jak pisze uczony opat - tylko wtedy przyniesic oczekiwane owoce, o ile ze strony duchowieństwa spotka ją właściwe usposobienie względem modlitwy liturgícznej w ogólności. Wymaga to przygotowania już w szkole i w seminarium, ale obok wyksztalcenia równieź i pobożności mocno opartej na tajemnicach Chrystusowych i zrozumienia dla wartości religijnych i literackich Pisma św., którym siẹ karmić powinna dusza kapłańska.

Czasopismo „Paroisse et liturgie“ ma już za sobą 50 lat pracy. Od początku sluży wiernie swoim zasadom. Nie przeznaczone dla uczonych rozpraw usiluje spelnić swe zadanie przez umiejętne i nieustanne omawianie rzeczy prostych, a wszystkich obchodzących. Zwracając się do parafian, chce ich pociągnąć do osoby ich proboszcza i do życia z Kościolem, a mianowicie z. kościolem parafialnym. Z drugiej też strony i duszpasterzom ułatwia wymianę myśli i korzystanie z cudzych doświadczeń. Pod różnymi nazwami i postaciami docieralo do szerokich warstw belgijskiego spoleczeństwa, ciempliwie i uparcie żlobiąc kanały dla swoich haseł. Dziś stojąc już wśród najbardziej zasłużonych bojowników ruchu liturgicznego, może spokojnie spojrzeć na swój 50-letni dorobek, bo owoce dzialanlia są już widoczne.

\section{Z FRANCJI}

W dniach 15-15 września obradował w Wersalu Zjazd C. P. L. przy udziale około 400 osób. Położono nacisk na wlaściwe ujęcie teoretyczne liturgii, która nie jest jakimś „misjonarskim chwytem“; ale „dziełem zbawienia, które wiernym przedstawiajạ kaplańskie ręce Kościoła św.". Jej zrozumienie zależy od wnikniẹcia w tajemnice Chrystusowe, które dokonujạ 
się na naszych oczach pod zasłoną Sakramentów św. O. Bernard Botte mówil o pięknym i godnym sposohie odprawiania nabożeństw, o roli kapłana jako pośrednika w zgromadzeniu wiernych, jako Chrystusa obecnego wśród ludu i o roli kazania jako slowa Bożego. Piękny i bogaty w treść zjazd wersalski uczy także, że ważną w ruchu liturgicznym jest sprawa porozumienia, zespolenia wysilków i kierownictwa.

Echem encykliki ,Mediator Dei“ jest artykuł O. Bergha, jezuity, w Revue des communautés réligieuses" o zjednoczeniu życia liturgícznego i ćwiczeń pobożnych. Autor ulożył swe wywody w rodzaju konstytucji dla zgromadzenia, które by urzeczywistniało wszystkie wskazówki encykliki. Będzile to $\mathrm{z}$ wielką korzyścią dla calego ruchu liturgicznego, gdy zgromadzenia w jaknajszerszej mierze przyswoją sobie ducha nauk Ojca św.

Z końcem roku 1948 wszedl w użycie nowy rytuał, posługujący się wydatnie językiem francuskim obok lacińskiego. Wśród formuł i modlitw niektóre należy wypowiadać tylko po lacinie, inne tylko po francusku, inne w dowolnym języku, a jeszcze inne po wypowiedzeniu po łacinie wolno odczytać powtórnie po francusku. Odnośnie posługiwania Św. Sakramentów, przepisy są następujące:

chrzest - formuly pomazania po lacinie, reszta dowolnie;

bierzmowanie - wszystko po łacinie, kapłan równocześnie wyjaśnia;

ostatnie namaszczenie - formuly namaszczenia po lacinie reszta dowolnie;

sakrament małżeństwa - po lacinie formula i błogosławieństwo obrączek.

Nowy rytual stanowi bezsprzecznie wielki krok naprzód: ułatwia wiernym rozumienie $s w$. czynności a kaplanom ich wyjaśnianlie; niemniej nosi jeszcze piętno czegoś przejściowego i niedoskonalego. Zwłaszoza tłumaczenia bywają nieszczęśliwe i wymagają poprawek. Może te braki są już zapowiedzią dalszych zmian i postępów w tej dziedzinie.

Tyniec.

O. Pawel Sczaniecki.

\section{POLONIA SACRA KU CZCI KS. WUJKA}

Wyszedł osobny zeszyt ku czci Ks. Wujka - nr. 1 i 2 na rok 1950, w którym są następujące prace:

Autobiografia Ks. J. Wujka, Jan Otrębski: Uczcijmy Ks. J. Wujka, Ks. Jan Poplatek: Obecny. stan badań nad życiem J. Wujka, Konrad Górski: Ks. Jakub Wujek, jako pisarz, Ks. Franciszek Bracha, Ks. Jakub Wujek, jako dogmatyk, Ks. Teofil Długosz: „Postylla mniejsza“ Ks. J. Wujka. 